\title{
EFEK PROBIOTIK Bacillus megaterium PTB 1.4 DAN Pediococcus pentosaceus E2211 TERHADAP REPONS IMUN DAN KELANGSUNGAN HIDUP IKAN LELE (Clarias sp.) SELAMA UJI TANTANG Aeromonas hydrophila
}

\author{
Muhammad Subhan Hamka $^{a}$, Anja Meryandinib, Widanarnib ${ }^{b}$, Ardana Kurniaji ${ }^{*}$ \\ aAkademi Komunitas Negeri Rejang Lebong, Jln. Basuki Rahmad No. 27, Rejang Lebong, Bengkulu, \\ Indonesia \\ ${ }^{b}$ Institut Pertanian Bogor, Jln. Raya Dramaga, Bogor, Jawa Barat, Indonesia \\ 'Politeknik Kelautan dan Perikanan Bone, Jln. Sungai Musi, Bone, Sulawesi Selatan, Indonesia \\ *Koresponden penulis: ardana.kji@gmail.com
}

\begin{abstract}
Abstrak
Penyakit bakterial pada kegiatan budidaya ikan sudah menjadi masalah yang sering dihadapi pembudidaya. Salah satu jenis bakteri yang menyebabkan penyakit pada ikan lele (Clarias sp.) adalah bakteri Aeromonas hydrophila. Tujuan penelitian ini untuk mengevaluasi efek pemberian probiotik Bacillus megaterium PTB 1.4 dan Pediococcus pentosaceus E2211 terhadap respons imun dan kelangsungan hidup ikan lele selama uji tantang dengan bakteri $A$. hyrophila. Probiotik yang digunakan adalah kombinasi $0,5 \%$ B. megaterium PTB 1.4 dan 0,5\% P. pentosaceus E2211. Pemberian probiotik dilakukan pada hari ke-0 hingga hari ke-30 melalui pakan. Uji tantang dilakukan pada hari ke-30 hingga hari ke-40. Hasil penelitian menunjukkan bahwa pemberian probiotik dapat berpengaruh terhadap respons imun dan kelangsungan hidup ikan lele dalam menekan infeksi A. hydrophila. Total eritrosit, hemoglobin, hematokrit, total leukosit, aktivitas fagositik dan aktivitas lisozim signifikan $(\mathrm{P}<0,05)$ teramati meningkat pada hari ke-35 dan menurun pada hari ke-40. Kelangsungan hidup ikan lele berhasil dipertahankan pada 87,62 $\pm 4,83 \%$. Total bakteri $A$. hydrophila meningkat pada hari ke-35 dan menurun pada hari ke-40. Pemberian probiotik B. megaterium PTB 1.4 dan P. pentosaceus E2211 pada dosis 0,5\% dapat menekan pertumbuhan bakteri A. hydrophila dan meningkatkan status kesehatan ikan lele.
\end{abstract}

Kata kunci: Aeromonas hydrophila, kelangsungan hidup, probiotik, respons imun

\begin{abstract}
Bacterial diseases in aquaculture activities has become a problem often faced by farmers. One type of bacteria that causes disease in catfish (Clarias sp.) is Aeromonas hydrophila bacteria. The aim of this study that to evaluate the effect of probiotics Bacillus megaterium PTB 1.4 and Pediococcus pentosaceus E2211 on the immune response and survival of catfish during a challenge test with $A$. hyrophila bacteria. The probiotics used were combination of $0.5 \%$ B. megaterium PTB 1.4 and $0.5 \%$ P. pentosaceus E2211. Provision of probiotics was given on day- 0 to day-30 through feed. The challenge test was carried out on day 30 to day 40. The results showed that the administration of probiotics could affect the immune response and survival rate of catfish in suppressing A. hydrophila infection. Total erythrocytes, hemoglobin, hematocrit, total leukocytes, phagocytic activity and lysozyme activity were significant $(\mathrm{P}<0.05)$ increasing on day-35 and decreasing on day-40. The survival rate of catfish was successfully maintained at $87.62 \pm 4.83 \%$. Total $A$. hydrophila bacteria increased on the day-35 and decreased on the day-40. Administration of probiotics $B$. megaterium PTB 1.4 and P. pentosaceus E2211 at a dose of $0.5 \%$ can suppress the growth of A. hydrophila bacteria and improve the health status of catfish.
\end{abstract}

Keywords: Aeromonas hydrophila, immune respons, probiotics, survival rate

\section{PENDAHULUAN}

Penyakit menjadi salah satu faktor pembatas produksi budidaya ikan karena dapat menyebabkan kerugian baik pada kegiatan pembenihan maupun pembesaran ikan. Penyakit ikan biasanya disebabkan karena stres akibat kualitas air yang buruk, nutrisi pakan buruk, padat penebaran tinggi dan infeksi patogen [1]. Penyakit infeksius yang sering 
dijumpai pada kegiatan budidaya ikan adalah penyakit yang disebabkan oleh bakteri [2]. Penyakit bakterial pada kegiatan budidaya ikan sudah menjadi masalah yang sering dihadapi pembudidaya. Perkembangan penyakit ini tidak hanya bergantung pada kemampuan bakteri menyebabkan gangguan kesehatan pada ikan, tetapi juga kondisi imunitas, lingkungan dan tingkat virulensi dari bakteri tersebut [3].

Salah satu jenis bakteri yang menyebabkan penyakit pada ikan air tawar adalah bakteri Aeromonas hydrophila. Bakteri ini merupakan salah satu jenis bakteri yang umum ditemukan dalam budidaya ikan komoditas air tawar selain Flexibacter columnaris, Edwardsiella tarda dan Streptococcus iniae [4]. A. hydrophila merupakan strain bakteri yang memiliki virulensi tertinggi karena dapat menyebabkan kematian hingga 100\% [5], dan dapat hidup pada kisaran suhu, $\mathrm{pH}$ dan kekeruhan yang luas dengan rentang parameter lingkungan yang tinggi [6]. Bakteri ini adalah jenis bakteri gram negatif yang oportunistik, berbentuk batang dan mampu melisis arginin, idole, lysine dan lainnya. Produk ekstraseluler bakteri digunakan untuk menginfeksi inang dan produk intraseluler dihasilkan saat bakteri mati [7].

Bakteri A. hydrophila secara selektif dapat menginfeksi ikan lele, ikan mas, ikan nila dan salmon pada perairan tawar. [6]. Ikan yang ditemukan terinfeksi bakteri $A$. hydrophila menunjukkan gejala berupa ulserasi pada kulit dan sirip, pembengkakan pada organ dalam seperti lambung dan usus, luka hemoragik [8]. Pada kondisi tertentu ikan yang terinfeksi $A$. hydrophila mengalami pendarahan pada organ, berenang abnormal, ulserasi, sisik lepas dan geripis, hipertrofi dan hiperflasia [9]. Penyakit ini juga bisa menjadi infeksi sistemik dan disebut Motile Aeromona d Septicemia (MAS) [10].

Infeksi A. hydrophila ditemukan pertama kali di wilayah Jawa Barat tahun 1980 dan biasanya ditemukan pada budidaya ikan lele. Kasus kerugian akibat penyakit ini telah banyak ditemukan salah satu diantaranya di Jawa Timur dengan prevalensi kasus infeksi 95\% pada ikan lele dumbo di Keramba Jaring
Apung [11]. Kasus kematian ikan lele terus terjadi pada tahun 2003 dan 2004 di Wilayah Banyumas [12]. Salah satu upaya yang dilakukan untuk menekan infeksi $A$. hydrophila pada ikan lele adalah dengan aplikasi probiotik.

Probiotik adalah mikroorganisme hidup yang dapat memberikan keuntungan pada inangnya. Aplikasi probiotik telah banyak digunakan untuk pengendalian penyakit ikan [13]. Terdapat tiga peran probiotik secara umum yakni menekan populasi mikroba lain, merubah metabolisme mikrobial melalui aktivitas enzim dan mensitmulus imunitas [14]. Jenis probiotik untuk kegiatan budidaya perikanan juga telah banyak diteliti [15] - [19]. Salah satu probiotik yang telah ditemukan dan mampu meningkatkan pertumbuhan ikan lele adalah bakteri Bacillus megaterium PTB 1.4 yang diisolasi dari saluran pencernaan ikan lele [20], dan Pediococcus pentosaceus E2211 yang diisolasi dari hasil fermentasi spontan tepung jagung [21]. Kedua bakteri ini telah dilaporkan mampu meningkatkan pertumbuhan dan imunitas ikan lele dari infeksi A. hydropilla pada dosis $1 \%$ [22]. Probiotik ini diaplikasikan dengan metode oral atau pemberian pakan. Probiotik umumnya merupakan mikroorganisme fermentatif yang jika dicampur pakan maka akan meningkatkan kualitas pakan [14]. Hasil penelitian terkait kombinasi kedua bakteri probiotik dengan dosis $0,5 \%$ pada pakan belum dilakukan. Penelitian ini bertujuan untuk mengevaluasi efek pemberian probiotik $B$. megaterium $\mathrm{PTB}$ 1.4 dan P. pentosaceus E2211 terhadap respons imun dan kelangsungan hidup ikan lele selama uji tantang dengan bakteri $A$. hyrophila pada dosis $0,5 \%$ yang diaplikasikan melalui pakan.

\section{METODE}

Penelitian ini dilaksanakan di Institut Pertanian Bogor. Untuk preparasi probiotik dilaksanakan di Laboratorium Bioteknologi Hewan dan Biomedis, PPSHB LPPM IPB. Pemeliharaan ikan lele dan uji tantang dengan A. hydrophila dilaksanakan di kolam penelitian pesantren Nur Ar Rohman, Desa Tegal Waru, Kabupaten Bogor. Pengamatan parameter 
imunitas dilaksanakan di Laboratorium Kesehatan Ikan, Departemen Budidaya Perairan, Fakultas Perikanan dan Ilmu Kelautan IPB.

\section{Kultur Bakteri Probiotik}

Bakteri probiotik yang digunakan dalam penelitian ini adalah $B$. megaterium $\mathrm{PTB}$ 1.4 [20] dan $P$. pentosaceus E2211 [21]. Bakteri dikultur dan diberi penanda resisten antibiotik Rifampisin. Media Triptic Soy Broth (TSB) digunakan untuk kultur bakteri $B$. megaterium PTB 1.4: Metode kultur dengan inkubasi pada water bath shaker $140 \mathrm{rpm}$ dan suhu $29^{\circ} \mathrm{C}$ selama 12 jam. Media deMan, Rogosa, and Sharpe Broth (MRSB) digunakan untuk kultur bakteri $P$. pentosaceus E2211 dengan metode inkubasi menggunakan anaerobic jar pada suhu $37^{\circ} \mathrm{C}$ selama 18 jam. Pada akhir masa kultur, pellet bakteri dipanen dengan menggunakan sentrifuge pada 9.000 rpm selama 5 menit. Selanjutnya pellet yang dihasilkan dilarutkan pada $0,1 \mathrm{~mL} \mathrm{NaCl} 0,85 \%$ steril.

\section{Persiapan Pakan}

Pakan yang digunakan adalah pakan komersial dengan komposisi protein $39-41 \%$, lemak min. 5\%, serat maksimal $6 \%$, abu maksimal $18 \%$ dan kadar air maksimal $10 \%$. Bakteri yang telah disiapkan sebelumnya dipanen pada umur 12-18 jam kemudian dicampur pada pakan komersial. Pencampuran dilakukan dengan dosis $0,5 \%$ probiotik $B$. megaterium PTB 1.4 dan dosis $0,5 \%$ probiotik P. pentosaceus E2211. Viabilitas bakteri diuji setelah bakteri dicampur di pakan. Pengujian menggunakan media tumbuh bakteri dengan campuran $50 \mu \mathrm{g} / \mathrm{mL}$ rifampisin. Hasil pengujian diperoleh bahwa viabilitas bakteri probiotik pada pakan sebesar $10^{6} \mathrm{CFU} / \mathrm{g}$ pakan. Selanjutnya pakan dapat diaplikasikan pada ikan dengan pemberian tiga kali sehari.

\section{Preparasi Media Pemeliharaan Ikan}

Pemeliharaan ikan dilakukan pada waring berukuran $100 \times 30 \times 80 \mathrm{~cm}^{3}$ yang dipasang dalam kolam beton berisi air tawar yang diperoleh dari sungai sekitar tempat penelitian. Terlebih dahulu media pemeliharaan dibersihkan dari hama dan kotoran. Kemudian dijemur dan diisi air dengan kedalaman $50 \mathrm{~cm}$. Perlakuan air meliputi pemberian kapur 277,78 ppm, molase 55,56 ppm, pupuk kandang 555,56 ppm dan ragi $1,1 \mathrm{ppm}$. Air yang telah diberi perlakuan kemudian dibiarkan selama 7 hari sebelum digunakan.

\section{Persiapan dan Pemeliharaan Ikan Uji}

Ikan yang digunakan dalam penelitian ini adalah ikan lele (Clarias sp.) dengan bobot $7,36 \pm 0,21$ g/ekor. Ikan diperoleh dari pembudidaya di Kabupaten Bogor, Jawa Barat. Saat penebaran, ikan terlebih dahulu diaklimatisasi selama satu minggu dengan pemberian pakan biasa (tanpa probiotik) dengan frekuensi tiga kali sehari secara at satiation. Kepadatan ikan diatur sebanyak 30 ekor/waring. Pemeliharaan ikan dilakukan selama 30 hari (1 bulan). Selama pemeliharaan ikan diberikan pakan dengan campuran probiotik dosis $0,5 \%$ B. megaterium PTB 1.4 dan $0,5 \%$ probiotik $P$. pentosaceus E2211 dengan frekuensi tiga kali sehari secara at satiation.

\section{Uji Tantang A. hydrophila}

Setelah pemeliharaan ikan lele selama 30 hari dengan pemberian pakan + probiotik, selanjutnya pada hari ke-31 dilakukan uji tantang. Uji tantang dilakukan selama 10 hari (hingga hari ke-40 pemeliharaan). Selama uji tantang ikan tidak diberikan probiotik atau pakan standar tanpa campuran bakteri probiotik dan dilakukan pengamatan mortalitas. Bakteri yang digunakan untuk uji tantang adalah bakteri $A$. hydrophila yang sebelumnya telah diremajakan. Suspensi bakteri diinjeksikan intramuscular dengan konsentrasi $10^{6} \quad \mathrm{CFU} / \mathrm{mL}$ sebanyak 0,1 mL/ekor menggunakan suntik steril volume 1 $\mathrm{mL}$

\section{Parameter Pengamatan}

Parameter yang diamati dalam penelitian ini meliputi respons imun, kelangsungan hidup pasca uji tantang dan populasi bakteri A. hydrophila. Pengamatan parameter respons imun dilakukan pada Hari ke-0, 30, 35 dan 40 pemeliharaan, sedangkan 
populasi bakteri diamati pada hari ke-30, 35 dan 40 hari pemeliharaan. Adapun tahapan pengujian parameter sebagai berikut:

\section{Respons Imun}

Parameter respons imun yang diamati yakni gambaran darah, aktivitas lisozim, aktivitas respiraroty burst, aktivitas fagositik. Darah ikan diambil pada pangkal ekor sebanyak $0,2 \mathrm{~mL}$ menggunakan suntik volume $1 \mathrm{~mL}$ yang berisi antikoagulan $(3,8 \%$ natrium sitrat). Darah selanjutnya dimasukkan dalam tube $1,5 \mathrm{~mL}$ dan disimpan pada suhu $4^{\circ} \mathrm{C}$ untuk pengujian selanjutnya. Total eritrosit dan total leukosit dihitung dengan metode [23] dengan rumus:

Sel Darah $\left(\mathrm{sel} / \mathrm{mm}^{3}\right)=\sum \mathrm{ST} \frac{1}{\text { Vol Kotak Besar }} \times F K$

Ket.

ST $=$ Sel Darah Terhitung

FK $=$ Faktor Pengenceran

Kadar Hematokrit dan aktivitas fagositik (AF) dihitung dengan mengacu pada [24]:

Hematokrit $(\%)=\frac{\text { panjang endapan darah }}{\text { panjang seluruh darah }} \times 100$

$\mathrm{AF}(\%)=\frac{\sum \text { sel fagosit melakukan fagosit }}{\sum \text { sel fagosit }} \times F K$

Kadar hemoglobin diukur menggunakan metode Sahli [25]. Adapun aktivitas respiratory burst dianalisis dengan mengacu pada metode [26] dan aktivitas lisozim mengacu pada metode [27].

\section{Kelangsungan Hidup}

Kelangsungan hidup dihitung setelah uji tantang. Perhitungan kelangsungan hidup mengacu pada metode [28] dengan rumus:

$$
\mathrm{KH}(\%)=\frac{\text { Jumlah Ikan Akhir }(\text { ekor })}{\text { Jumlah Ikan Wal (ekor) }} \times 100
$$

\section{Total Bakteri A. hydrophila}

Perhitungan total bakteri A. hydrophila dilakukan pada hari ke-30, 35 dan 40 dengan mengacu pada metode [29]. Organ target yang dijadikan sampel adalah hati dan ginjal yang diambil masing-masing sebanyak $0,1 \mathrm{~g}$. Sampel kemudian digerus dan diencerkan secara berseri pada larutan PBS steril. Hasil pengeceran disebar pada media Rimler-shotts (RS) sebanyak $0,05 \mathrm{~mL}$ untuk mengetahui jumlah bakteri dilakukan metode total plate count (TPC).

\section{Analisis data}

Data yang telah diperoleh berupa gambaran darah, aktivitas lisozim, aktivitas respiraroty burst, aktivitas fagositik, kelangsungan hidup dan total bakteri ditabulasi dengan microsoft office dan dianalisis secara statistik setiap waktu pengamatan. Analisis data menggunakan oneway-ANOVA (analysis of variance) melalui program SPSS versi 16 dengan selang kepercayaan $95 \%$, perbedaan antar perlakuan dilanjutkan dengan uji Duncan.

\section{HASIL DAN PEMBAHASAN}

\section{Respons Imun dan Kelangsungan Hidup}

Hasil penelitian menunjukkan bahwa aplikasi probiotik dosis $0,5 \%$ B. megaterium PTB 1.4 dan $0,5 \%$ probiotik $P$. pentosaceus E2211 memberikan pengaruh terhadap performa respons imun ikan lele. Adapun hasil pengamatan respons imun dan kelangsungan hidup ikan lele dapat dilihat pada tabel berikut: 
Tabel 1. Respons imun dan kelangsungan hidup ikan lele

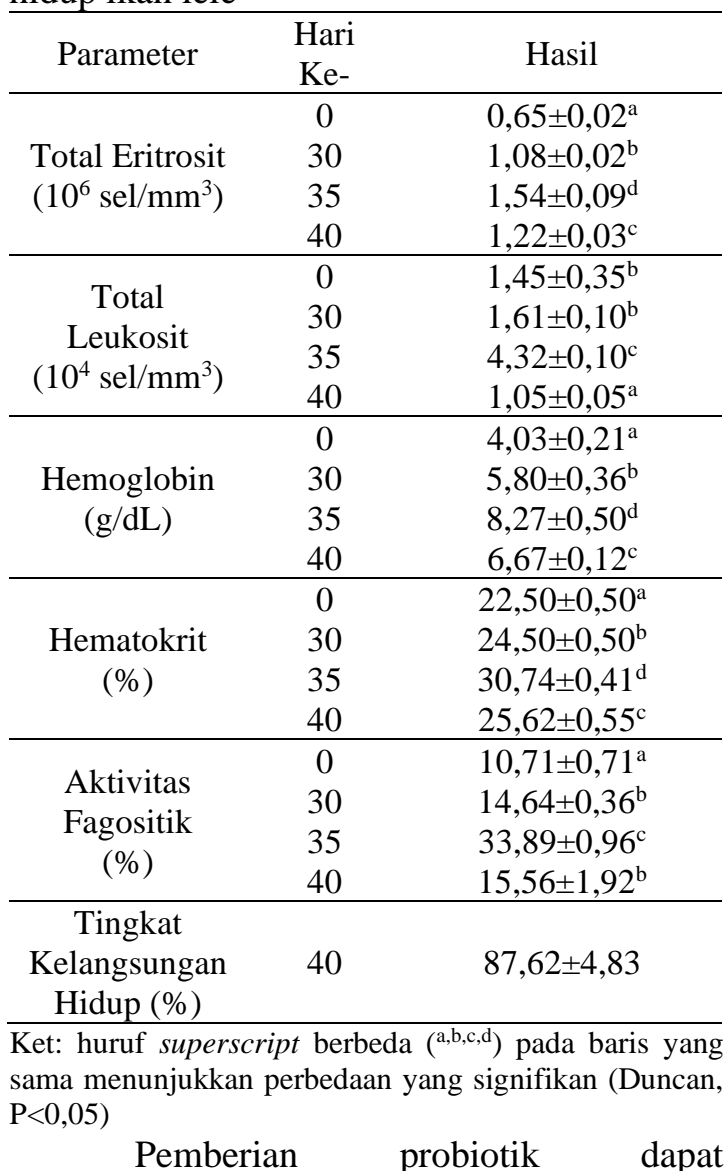
mempertahankan kelangsungan hidup ikan lele yang diuji tantang $A$. hydrophila sebesar 87,62 $\pm 4,83 \%$. Sejalan degan hasil [17] bahwa kelangsungan hidup ikan lele yang diberi $P$. pentosaceus E2211 dan diuji tantang $A$. hydrophila sebesar $88,46 \%$, sehingga probiotik sangat berperan penting dalam menjaga kesehatan ikan dari infeksi patogen. Ikan lele yang terinfeksi bakteri $A$. hydrophila biasanya mengalami mortalitas hingga $90 \%$ dalam waktu 48 jam [30]. Beberapa penelitian menunjukkan bahwa ikan lele yang diuji tantang dengan $A$. hydrophila mengalami kematian hingga $100 \%$ [31],[32],[33]. Probiotik berperan dalam meningkatkan imunitas ikan sehingga mencegah infeksi patogen [34].

Respons imun dapat diamati dari parameter gambaran darah ikan yakni total eritrosit, total leukosit, hematokrit, hemoglobin [28]. Total eritrosit pada penelitian ini menunjukkan perbedaan nyata $(\mathrm{P}<0,05)$ antara setiap waktu pengamatan. Total eritrosit terendah diamati pada hari ke-0 (awal) kemudian meningkat secara signifikan pada hari ke-30 dan mencapai nilai tertinggi pada hari ke-35. Total eritrosit pada hari ke-40 secara signifikan mengalami penurunan dari pengamatan sebelumnya. Kisaran nilai total eritrosit yang teramati adalah $0,65-1,54 \times 10^{6}$ $\mathrm{sel} / \mathrm{mm}^{3}$. Kisaran ini masih termasuk dalam kategori normal sebagaimana pernyataan [35] bahwa total eritrosit ikan lele sehat adalah 1,0$3,0 \times 10^{6} \mathrm{sel} / \mathrm{mm}^{3}$. Peningkatan total eritrosit terjadi setelah uji tantang sebagai bentuk repons stres karena infeksi patogen. Ikan yang stres biasanya mengalami peningkatan eritrosit karena mengganti sel eritrosit yang lisis akibat infeksi [36].

Peningkatan total leukosit biasanya diikuti oleh perubahan kadar hemoglobin [37]. Kadar hemoglobin ikan lele pada penelitian ini menunjukkan fluktuasi yang sama dengan total eritrosit. Nilai terendah teramati pada hari ke-0 (awal) pengamatan. Selanjutnya secara signifikan meningkat pada hari ke-30 dan mencapai nilai tertinggi pada hari ke-35. Kadar hemoglobin menurun pada hari ke-40 dan berbeda nyata dengan pengamatan sebelumnya $(\mathrm{P}<0,05)$. Kisaran kadar hemoglobin yang diamati adalah 4,03-8,27 g/dL. Bakteri $A$. hydrophila menghasilkan eksotoksin yang dapat melisis sel darah merah dan membebaskan hemoglobinnya [38]. Kadar hemoglobin berkorelasi dengan total eritrosit. Semakin tinggi hemoglobin semakin tinggi total eritrosit [39].

Fluktuasi hemoglobin juga berkaitan dengan kadar hematokrit. Hasil pengamatan kadar hematokrit juga menunjukkan hal yang sama dengan kadar hemoglobin. Nilai terendah teramati pada hari ke-0 (awal) pengamatan dan terus meningkat secara signifikan hingga hari ke-35. Nilai tertinggi diamati pada hari ke-35. Kadar hematokrit menurun secara signifikan pada hari ke-40 pengamatan. Kisaran nilai kadar hematokrit adalah $22,50-30,74 \%$. Nilai ini masih dalam kondisi normal yakni antara 20-35\% [40]. Peningkatan kadar hematokrit diduga karena adanya infeksi saat uji tantang. Ikan yang terinfeksi bakteri A. hydrophila biasanya akan mengalami peningkatan kadar hematokrit [41]. Hematokrit merupakan jumlah sel darah merah terhadap volume darah 
dalam satuan persen sehingga fluktuasinya diikuti dengan eritrosit. Adanya peningkatan total eritrosit, hemoglobin dan hematokrit pada hari ke-0 hingga 30 (sebelum uji tantang menunjukkan adanya respon ikan terhadap pemberian probiotik. Keberadaan probiotik diduga meningkatkan status kesehatan ikan sehingga dapat membantu menetralisir infeksi patogen. Hal ini diketahui dari nilai total eritrosit, hemoglobin dan hematokrit yang masih dalam kisaran normal meskipun meningkat pada saat uji tantang.

Pengamatan pada total leukosit menunjukkan hasil yang tidak berbeda nyata pada hari ke-0 (awal) dan hari ke-30 $(\mathrm{P}>0,05)$. Hal ini menunjukkan bahwa pemberian probiotik tidak secara signifikan mempengaruhi total leukosit. Peningkatan secara signifikan baru terjadi setelah uji tantang yakni pada hari ke-35 pengamatan. Total leukosit mengalami penurunan terendah pada hari ke-40 sehingga berbeda nyata dengan hari pengamatan sebelumnya. Leukosit merupakan sel imunitas yang berperan dalam sistem kekebalan non-spesifik. Jumlahnya dapat menjadi indikator status kesehatan ikan. Adanya infeksi menyebabkan total leukosit meningkat untuk melawan infeksi bakteri $A$. hydrophila [22]. Leukosit akan berdiferensiasi menjadi sel-sel makrofag (antigen precenting cells) untuk aktivitas fagositosis. Oleh karena itu peningkatan total leukosit berkorelasi dengan peningkatan aktivitas fagositik. Leukosit merupakan komponen darah yang salah satu fungsinya adalah fagositosis [42].

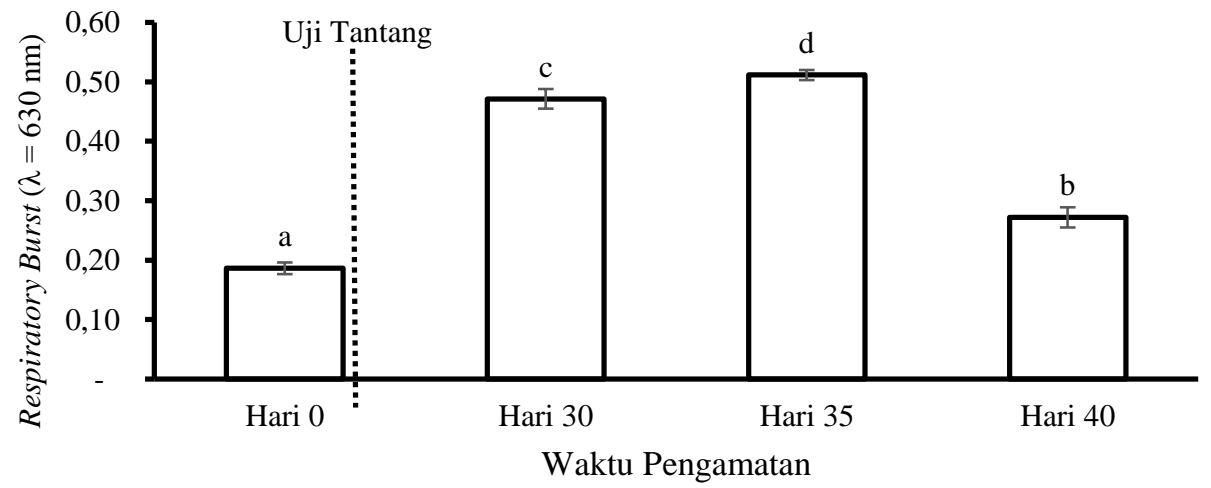

Gambar 1. Aktivitas respiratory burst $(\lambda=630 \mathrm{~nm})$ ikan lele, huruf superscript berbeda $\left(^{(\mathrm{a}, \mathrm{b}, \mathrm{c}, \mathrm{d}}\right)$ pada baris yang sama menunjukkan perbedaan yang signifikan (Duncan, $\mathrm{P}<0,05$ )

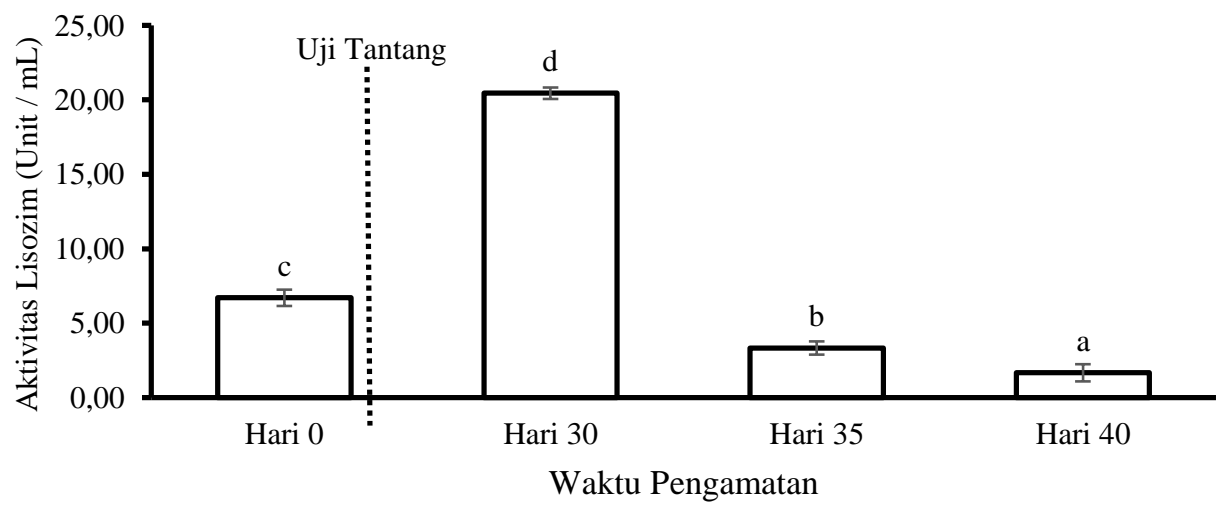

Gambar 2. Aktivitas lisozim (Unit/mL) ikan lele, huruf superscript berbeda $\left({ }^{\mathrm{a}, \mathrm{b}, \mathrm{c}, \mathrm{d}}\right)$ pada baris yang sama menunjukkan perbedaan yang signifikan (Duncan, $\mathrm{P}<0,05$ )

Hasil pengamatan aktivitas fagositik menunjukkan bahwa nilai rendah pada awal pengamatan dan meningkat secara signifikan pada hari ke-30. Peningkatan aktivitas fagositik terus terjadi secara signifikan pada hari ke-35 dan menurun pada hari ke-40. Tidak ada perbedaan nyata antara aktivitas fagositik pada hari ke-30 dan 40. Aktivitas fagositik 
memiliki peranan dalam melisis patogen dan mempresentasikannya di permukaan sel untuk dikenali sebagai antigen [43].

Fagositosis merupakan pertahanan tubuh awal untuk membatasi dan menghancurkan benda asing. Jenis sel fagosit yakni monosit dan neutrophil. Umumnya aktivitas fagositik sinergi dengan respiratory burst dan aktivitas lisozim dalam menetralisir patogen [44]. Pengamatan respiratory burst menunjukkan nilai rendah pada awal pengamatan (hari ke-0) selanjutnya meningkat secara signifikan pada hari ke-30 hingga hari ke-35, dan pada hari ke-40 menurun secara nyata seperti yang ditunjukkan pada Gambar 1. Kondisi ini menunjukkan adanya korelasi positif antara peningkatan leukosit dan respiratory burst saat tubuh ikan mengalami infeksi. Penurunan nilai respiratory burst pada hari ke-40 diduga sebagai bentuk recovery ikan menjadi normal. Aplikasi probiotik $B$. megaterium PTB 1.4 dan $P$. pentosaceus E2211 pada dosis 1\% dapat membantu proses recovery ikan lele pada hari ke-10 setelah terinfeksi A. hydrophila [22]. Selanjutnya pada
Gambar 2 menunjukkan aktivitas lisozim diamati meningkat secara signifikan pada hari ke-30 dan perlahan menurun pada hari ke-35 dan 40. Pemberian probiotik dapat menstimulus peningkatan aktivitas lisozim. Menurut [34] bahwa probiotik dapat memicu lisozim pada ikan teleostei. Penurunan nilai lisozim diduga karena masa recovery ikan menuju normal.

\section{Total Bakteri Aeromonas hydrophila}

Pengamatan total populasi bakteri $A$. hydrophila dilakukan sebelum dan setelah uji tantang pada organ target yakni hati dan ginjal. Hasil pengamatan pada organ hati yang disajikan pada Gambar 3. menunjukkan bahwa bakteri A. hydrophila hari ke-30 (sebelum uji tantang) berkisar antara 4,0 $00,02 \mathrm{log}$ CFU/g. Selanjutnya meningkat secara signifikan pada total populasi tertinggi hari ke-35 (pasca uji tantang) berkisar 5,45 $\pm 0,03 \mathrm{log} \mathrm{CFU} / \mathrm{g}$. Total bakteri menurun secara signifikan pada hari ke-

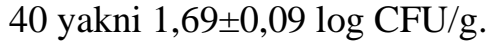

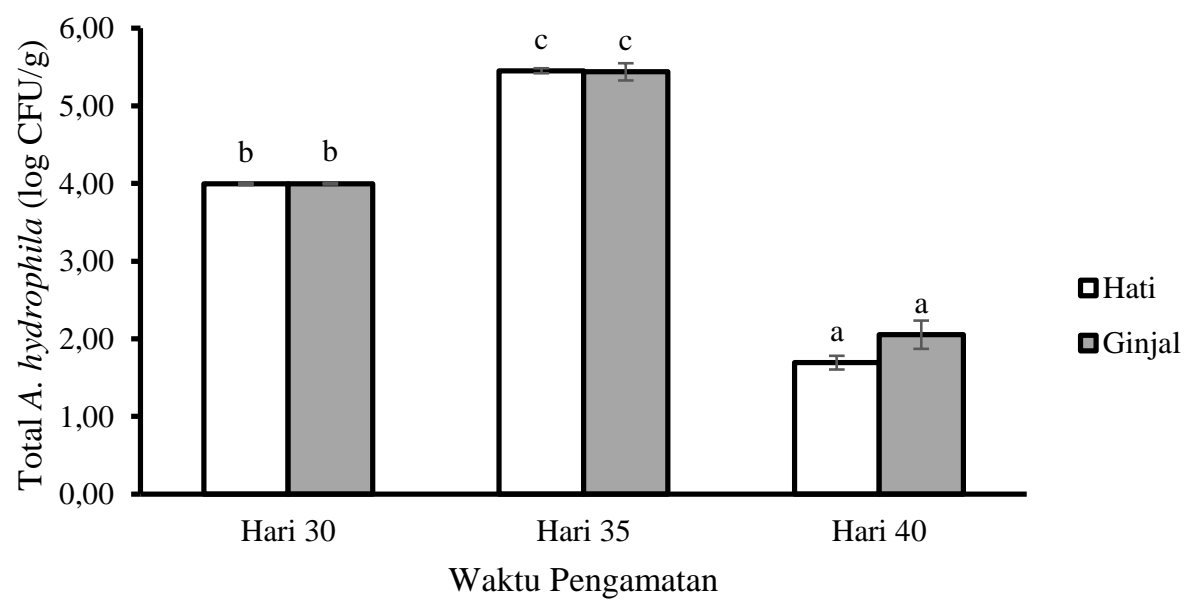

Gambar 3. Total bakteri A. hydrophila (log CFU/g) pada organ hati dan ginjal ikan lele, huruf superscript berbeda $\left({ }^{a, b, c, d}\right)$ pada baris yang sama menunjukkan perbedaan yang signifikan (Duncan, $\mathrm{P}<0,05$ )

Hasil pengamatan pada organ ginjal juga yang disajikan pada Gambar 3. menunjukkan hal yang sama yakni pada hari ke-30 (sebelum uji tantang) berkisar antara 4,0 $0,01 \log$ CFU/g. Selanjutnya meningkat secara signifikan pada total populasi tertinggi hari ke-35 (pasca uji tantang) berkisar 5,44 $\pm 0,11 \log \mathrm{CFU} / \mathrm{g}$. Total bakteri menurun secara signifikan pada hari ke40 yakni 2,05 $\pm 0,18 \log$ CFU/g. Peningkatan populasi bakteri pada hati dan ginjal hari ke-35 menunjukkan bahwa bakteri A. hydrophila yang diinjeksikan pada masa uji tantang 
tumbuh dan berkembang pada organ target. Hal ini menyebabkan berbagai perubahan parameter imunitas sebagai bentuk respons pertahan tubuh.

Bakteri A. hidrophila umumnya menginfeksi hati, ginjal, kulit dan usus dan menghasilkan biofilm, hemolisin, enzim lipase [45]. Kerusakan hati dan ginjal menyebabkan ikan sakit dan menurunkan nafsu makan dan kemampuannya bertahan hidup [42]. Adanya pemberian probiotik sebelum uji tantang diduga erat berkaitan dengan penurunan populasi bakteri A. hydrophila secara signifikan terjadi pada hari ke-40. Pemberian probiotik dapat meningkatkan kelangsungan hidup ikan lele, menekan pertumbuhan bakteri A. hydrophila dan meningkatkan status kesehatan ikan [46].

\section{KESIMPULAN}

Pemberian kombinasi probiotik $B$. megaterium PTB 1.4 dan $P$. pentosaceus E2211 dengan dosis 0,5\% pada masing-masing bakteri dapat memberikan pengaruh positif pada respons imun dan mempertahankan kelangsungan hidup ikan lele hingga $87,62 \pm 4,83 \%$. Hal ini menyebabkan penurunan populasi bakteri A. hidrophila dan meningkatkan status kesehatan ikan.

\section{UCAPAN TERIMA KASIH}

Terima kasih kepada Departemen Budidaya Perairan, Departemen Biologi, Pusat Penelitian Sumberdaya Hayati dan Bioteknologi, Institut Pertanian Bogor serta Bapak H. Saiful Ilhamsyah Agus, pemilik Kolam Penelitian Pesantren Nur Ar Rahman, Ciampea, Bogor.

\section{DAFTAR PUSTAKA}

[1] R. Ç. Öztürk dan I. Altinok, "Bacterial and viral fish diseases in Turkey," Turk. J. Fish. Aquat. Sci., vol.14, no.1, hal. 275297, Feb 2014.

[2] P. K. Sahoo, A. Paul, M. K. Sahoo, S. Pattanayak, P. R. Kumar, dan B. L. Das, "Incidences of Infectious Diseases in
Freshwater Aquaculture Farms of Eastern India: A Passive Surveillance based Study from 2014-2018," J. Aquac. Res. Development, vol.11, no.1, hal. 579-584, Jan 2020

[3] A. Pȩkala-Safińska, "Contemporary threats of bacterial infections in freshwater fish," J. Vet. Res., vol.62, no.3, hal. 261-267, Dec 2018.

[4] S. M. Aly, "A Review of Fish Diseases in the Egyptian Aquaculture Sector. Working Report," Cgiar, hal. 1-41, Jul 2013.

[5] S. M. Ahmed dan A. M. Shoreit, "Bacterial haemorrhagic septicemia in Oreochromis niloticus at Aswan fish hatcheries," Assiut Vet. Med. J., vol.45, no.89, hal. 190-206), Jan 2001.

[6] J. M. Janda dan S. L. Abbott, "The genus Aeromonas: taxonomy, pathogenicity, and infection," Clin. Microbiol. Rev., vol.23, no.1, hal. 35-73, Jan 2010.

[7] E. H. Hardi, C. A. Pebrianto, dan G. Saptiani, "Toksisitas Produk Ekstraseluler dan Intraseluler Bakteri Pseudomonas sp. pada Ikan Nila (Oreochromis niloticus)," Jurnal Veteriner, vol.15, no.3, hal. 312322, Sep 2013.

[8] H. Kartikaningsih, Yahya, F. Z. Rohman, dan A. A. Jaziri, "Characteristics of Aeromonas hydrophila- infected Catfish (Clarias sp.)," presented at the IOP Conf. Ser.: Earth Environ. Sci., 2019.

[9] E. H. Hardi, C. A. Pebrianto, T. Hidayanti, dan R. T. Handayani, " Infeksi Aeromonas hydrophila melalui jalur yang berbeda pada ikan nila (Oreochromis niloticus) di Loa Kulu Kutai Kartanegara Kalimantan Timur," J. Ked. Hewan, vol.8, no.2, hal. 130-133, Sep 2014.

[10] B. Austin dan D. A. Austin, Bacterial Fish Pathogens Disease of Farmed and Wild Fish, Ed.4. Swiss, CH: Springer 
Netherlands, 2007.

[11] Y. T. Prayogi, R. Kusdarwati, dan Kismiyati, "Isolasi, identifikasi dan presentasi ikan lele dumbo (Clarias gariepinus) yang terinfeksi bakteri Aeromonas hydrophila yang dipelihara di keramba jaring apung di Bozem Moro Krembangan, Surabaya," J. Aqua. Fish Health, vol.5, no.2, hal. 22-27, Jun 2016.

[12] D. S. Mulia, "Keefektivan vaksin Aeromonas hydrophila untuk mengendalikan penyakit MAS (Motile Aeromonas Septicemia) pada gurami (Osphronemus gouramy Lac.)," J. Pemb. Pedesaaan, vol.7, no.1, hal.43-52, Apr 2007.

[13] P. M. Cruz, A. L. Ibáñez, O. A. M. Hermosillo, dan H. C. R. Saad, "Review Article: Use of Probiotics in Aquaculture," ISRN Microbiology, vol. 2012, hal 1-13, Agu 2021.

[14] A. Mansyur dan A. M. Tangko, "Probiotik: pemanfaatannya untuk pakan ikan berkualitas rendah," Media Akuakultur, vol.3, no.2, hal. 145-149, Des 2008

[15] M. S. Hamka, A. Meryandini, Widanarni, L. O. Wahidin, dan A. Kurniaji, "Peran probiotik Bacillus megaterium PTB 1.4 dan Pediococcus pentosaceus E2211 dalam meningkatkan pertumbuhan dan konsumsi pakan ikan lele (Clarias sp.)," Jurnal Perikanan Darat dan Pesisir, vol.1, no.2, hal. 46-54, Apr 2021.

[16] N. Tarigan, F. Meiyasa, G. K. Efruan, D. A. Sitaniapessy, dan D. U. Pati, "Aplikasi probiotik untuk pertumbuhan ikan lele (Clarias batrachus) di Kelurahan Malumbi, Sumba Timur," J. Mitra, vol.3, no.1, hal. 50-57, Mei 2019.

[17] E. R. Turnip, Widanarni, A. Meryandini, "Selection of lactic acid bacteria as a probiotic and evaluated its performance on gnotobiotic catfish Clarias sp.," Jurnal
Akuakultur Indonesia, vol.17, no.1, hal. 68-80, Mei 2018.

[18] W. Munaeni, M. Yuhana, dan Widanarni, "Effect of Micro-encapsulated Synbiotic at Different Frequencies for Luminous Vibriosis Control inWhite Shrimp (Litopenaeus vannamei)," Microbiology Indonesia, vol.8, no.2, hal. 73-80, Jun 2014.

[19] M. Arief, N. Fitriani, dan S. Subekti, "Pengaruh pemberian probiotik berbeda pada pakan komersial terhadap pertumbuhan dan efisiensi pakan ikan lele sangkuriang (Clarias sp.)," Jurnal Ilmiah Perikanan dan Kelautan, vol.6, no.1, hal. 49-53, Apr 2014.

[20] Hamtini, Widanarni, dan A. Meryandiri, "Isolasi dan seleksi Bacillus sp. dan ikan lele (Clarias sp.) serta potensinya sebagai probiotik," Jurnal Biologi Indonesia, vol.11, no.1, hal. 11-19, Jan 2015.

[21] E. Rosyidah, A. Meryandini, dan T. C. Sunarti, "The Use of Lactic Acid Bacteria and Cellulolytic Bacteria to Improve the Chemical Properties of Corn Flour," Makara J. Sci., vol.17, no.3, hal. 75-80, Des 2013.

[22] M. S. Hamka, A. Meryandini, dan Widanarni, "Growth performance and immune response of catfish Clarias sp. given probiotics Bacillus megaterium PTB 1.4 and Pediococcus pentosaceus E2211," Jurnal Akuakultur Indonesia, vol.19, no.1, hal. 50-60, Jun 2020.

[23] P. C. Blaxhall dan K. W. Daisley, "Routine haematological methods for use with fish blood," J. Fish Biol., vol.5, no.6, hal. 771-781. Nov 1973.

[24] D. P. Anderson dan A. K. Siwicki, "Basic hematology and serology for fish health programs" dalam Book Report: Disease in Asian Aquacuture II, M. Shariff, J. R. Arthur, dan J. P. Subasinghe, editor. FIlipina: Asian Fisheries Society, Fish 
Health Section, 1993, hal. 185-202.

[25] G. A. Wedemeyer dan W. T. Yasutake, "Clinical methods for the assessment of the effects of environmental stress on fish health," Amerika Serikat: U.S. Fish and Wildlife Service, 1977 hal. 18.

[26] C. J. Secombes, "Isolation of salmoid macrophages and analysis of their killing activity" dalam Tehniques in fish immunology, Vol 1, J. S. Stolen, T. C. Fletcher, D. F. Anderson, B. S. Roberson, W. B. von Mulsvinkel, editor. New Jersey: SOS Publications, Fair Haven, 1990, hal. 137-155.

[27] A. Hanif, V. Bakopoulos, dan G. J. Dimitriadis, "Maternal transfer of humoral specific and non-specific immune parameters to sea bream (Sparus aurata) larvae," Fish Shellfish Immunol., vol.17, no.5, hal. 411-435. Nov 2004.

[28] A. Kurniaji, S. Nuryati, S. Murtini, dan Alimuddin, "Maternal immunity response and larval growth of anti cyhv-3 dna vaccinated common carp (Cyprinus carpio) at different pre-spawning time," Pak. J. Biotechnol., vol.15, no.3, hal. 689698, Agu 2018

[29] J. P. Harley dan L. M. Prescott, "Laboratory Exercises in Microbiology," Edisi 5, New York: The McGraw-Hill Companies, 2002.

[30] D. Zhang, D Xu, dan C Shoemaker, "Experimental induction of motile aeromonas septicemia in channel catfish (Ictalurus punctatus) by waterborne challenge with virulent Aeromonas hydrophila," Aquaculture Reports, vol.3, hal. 18-23, Mei 2016.

[31] A. Zubaidah, S. Samsundari, dan Hidayaturrahmi, "Effectiveness of strychnine bush extract (Strychnos ligustrina Blume) on the prevalence and survival rate of Dumbo catfish (Clarias gariepinus) infected by Aeromonas hydrophila," Indonesian Journal of Tropical Aquatic, vol.2, no.1, hal. 1-8, Feb 2019.

[32] Q. Astria, S. Nuryati, K. Nirmala, dan Alimuddin, "Effectiveness of ambon banana stem juice as immunostimulatory against Aeromonas hydrophila infections in catfish Clarias gariepinus," Jurnal Akuakultur Indonesia, vol.16, no.2, hal 154-163, Jul 2017.

[33] A. Indriyanti, P. G. S. Julyantoro, dan N. P. P. Wijayanti, "Protection of Thiophenone in Catfish (Clarias sp.) Larvae When Challenged with Aeromonas hydrophila," Advances in Tropical Biodiversity and Environmental Sciences," vol.5, no.1, hal. 23-28, Feb 2021.

[34] S.K. Nayak, "Review: Probiotics and immunity: A fish perspective. Fish Shellfish Immunol., vol.29, no.1, hal. 214. Jul 2010

[35] I. E. Alamanda, N. S. Handajani, dan A. Budiharjo, "Penggunaan metode hematologi dan pengamatan endoparasit darah untuk penetapan kesehatan ikan lele dumbo (Clarias gariepinus) di kolam budidaya Desa Mangkubumen Boyolali," Biodiversitas, vol.8, no.1, hal 34-38, Jan 2007.

[36] E. H. Hardi, E. Harris, dan A. M. Lusiastuti, "Karakteristik dan Patogenisitas Streptococcus agalactiae Tipe $\beta$-hemolitik dan Non-hemolitik pada Ikan Nila," Jurnal Veteriner, vol.12, no.2, hal. 152-164. Nov 2011.

[37] S. Purwanti, Suminto, dan A. Sudaryono, "The description of blood profile catfish Clarias gariepinus that is fed with a combination of artificial feed and earthworm Lumbricus rubellus," Journal of Aquaculture Management and Technology, vol.3, no.2, hal. 53-60, Apr 2014. 
[38] Triyaningsih, Sarjito, dan S. B. Prayitno, "Patogenitas Aeromonas hydrophila yang diisolasi dari ikan lele dumbo (Clarias gariepinus) yang berasal dari Boyolali," Journal of Aquaculture Management and Technology, vol.3, hal. 11-17, Mar 2014.

[39] K. Alipin, dan T. A. Sari, "Indikator kesehatan ikan kerapu cantik (Epinephelus sp.) yang terdapat pada budidaya keramba Pantai Timur Pangandaran," Metamorfosa Journal of Biological Sciences, vol.7, no.2, hal. 285292, Sep 2020.

[40] B. T. Adeyemo, R. A. Obande, dan S. G. Solomon, "Haematological reference ranges of cultured Clarias gariepinus in the Lower Benue River Basin, Nigeria. Comparative Clinical Pathology," vol.23, Okt 2014.

[41] S. Rahmaningsih, M. Zenuddin, dan A. Sudianto, "Gambaran hematokrit darah ikan lele sangkuriang (Clarias gariepinus) yang diberi pakan serbuk daun majapahit (Cresentia cujete $\mathrm{L}$ ) dan diinfeksi dengan bakteri Aeromonas hydrophila. Jurnal Kelautan Dan Perikanan Terapan, vol.1, no.2, hal. 63-67, Des 2018.

[42] Sukenda, L. Jamal, D. Wahjuningrum, dan A. Hasan, "Penggunaan kitosan untuk pencegahan infeksi Aeromonas hydrophila pada ikan lele dumbo Clarias sp.," Jurnal Akuakultur Indonesia, vol.7, no.2, hal. 159-169, Feb 2008.

[43] I. Tizard, Veterinary Immunology: An Introduction. Edisi ke-10. Amerika Serikat, US: Elsevier Health Sciences. 2016.

[44] C. Uribe, H. Folch, R. Enriquez, dan G. Moran, " Innate and adaptive immunity in teleost fish: a review. Veterinarni Medicina, vol.56, hal. 486-503, Jan 2011.
"Virulence of Aeromonas hydrophila isolated from fresh water catfish," Journal of Biosciences and Medicines, vol.7, no.1, hal. 1-12, Jan 2019.

[46] A. M. Lusiastuti, T. Sumiati, dan W. Hadie, "Probiotik Bacillus firmus untuk pengendalian penyakit Aeromonas hydrophila pada budidaya ikan lele dumbo, Clarias gariepinus," Jurnal Riset Akuakultur, vol.8, no.2, hal. 253-264, Jul 2013.

[45] P. T. Fowoyo, dan F. Achimugu, 